


\title{
A TUDÁSMENEDZSMENT SZEREPE A TECHNOLÓGIAI KOMPETENCIÁK MENEDZSELÉSE SORÁN
}

\author{
ROLE OF KNOWLEDGE MANAGEMENT IN \\ MANAGING TECHNOLOGY COMPETENCES
}

PEKK Letícia, HÁRY András

Kulcsszavak: tudásmenedzsment, technológiai kompetencia, technológiai képességek, tudásbázis, technológiai tudás

Keywords: knowledge management, technological competence, technological skills, knowledge base, technological knowledge

JEL kód: 032 


\section{ÖSSZEFOGLALÓ}

A tudásmenedzsment fogalmi meghatározására és modell szintü viəsgálatára nagy mennyiségú és magas minöségü tudományos forrás áll rendelkeęésre. Jelen tanulmány arra tesz. kísérletet, hogy a tudásmenedżsment elméleti összefoglalója alapján kapcsolatot teremtsen a kutatásfejlesżtés, az innováció, a technológiai menedzsment és a technológiai kompetencia irányába. Enneke érdekében, a tudásmenedzsment elvi megállapitásait tovább-bontva kerül sor elóbb a kutatás-fejlesztés és innováció, illetve technológiamenedzsment oldali megközelitésre, majd a technológiai kompetencia ismert fogalmi meghatározásain keresztül a további értelmezésre. A technológiai kompetencia ipari megközrelitése kapcsán viðsgált definiciók szinte egységes ürenenete a₹, hogy a technológiai kompetencia a bumán jellegü képességek és a technikai képességek kö̃ös halmaza, amely ennek megfelelöen átfogó és komplex menedzsment megközelitést is kiván. A szakirodalmi források feldolgozása és következtetések. levonása mentén kerülnek feltárásra a kutatási kérdések által megfogalmazott célzott terïletek és kapcsolatok. A tanulmány végén követkęrtetések kerülnek megfogalmazásra, amelyek további kutatásokat készítenek eló. Megállapitható, hogy nincs egységes módsz̧ertani álláspont a napjaink változó környezetében szülkséges technológiai kompetenciák tudásmenedzsment-oldali megközzelitésére, illetve az. elérhetö mérési módszerek is csak részben alkalmasak. Ugyanakekor, rendkivül fontos téma nemcsak a vállalatok, hanem a kutatóintézeti saféra számára is.

\section{SUMMARY}

A large amount and high quality of scientific resources are available for the conceptual definition and model-level examination of knowledge management. The present study attempts to link research and development, innovation, technology management and technological competence based on a theoretical summary of knowledge management. To this end, the theoretical findings of knowledge management will be further broken down into an approach on the part of research and development and innovation and technology management, followed by further interpretation through the known conceptual definitions of technological competence. The message of the definitions examined in the context of the industrial approach to technological competence is that technological competence is a common set of human and technical skills, which accordingly requires a comprehensive and complex management approach. The targeted areas and relationships articulated by the research questions will be explored along with the processing of literature sources and the drawing of conclusions. At the end of the study, conclusions are drawn that will prepare further research. It can be stated that there is no accepted methodology against the required technological competencies, and their measurement methods are only partially 
adequate. At the same time, it is an extremely important topic not only for companies but also for academies.

\section{BEVEZETÉS}

A társadalmi igények mellett a technológiai fejlődés alapvető mozgatója a kutatásfejlesztés, amely napjainkban rohamosan utat tör magának újabb és újabb technikai irányok mentén. Mind a megalapozó kutatások, mind a piaci bevezetéshez közelebb álló fejlesztési szakasz során központi helyet foglal el a tudás alkalmazása, így a tudásmenedzsment területe kulcsfontosságú a piaci versenyképességhez szükséges technológiai kompetenciák felépítéséhez. Ezért az érintett szervezeteknek nagy hangsúlyt kell fektetniük a tudásmenedzsmentre mind a rövid távú terveik, mind a hosszú távú stratégiájuk kialakítása során. Ahhoz, hogy körvonalazzuk az innováció, mint hajtóerô, a kutatás-fejlesztés mint tudásgeneráló folyamat, és a technológiai kompetenciák, mint versenyképességi tényező közötti összefüggéseket a tudásmenedzsment szempontjából, különkülön szükséges megvizsgálni az egyes elemek fogalmi hátterét.

A cikk célja éppen ez, a tudásmenedzsmenthez kapcsolódó elméleti megközelítések oldaláról értelmezni a technológiai kompetenciához kötődő szervezeti aspektusokat. Az elemzés módszere a tudásmenedzsment releváns szakterületi elméleti hivatkozásainak célirányos feldolgozása mentén vezet rá a technológiai kompetenciákhoz kötődő következtetésekre. A jelen cikk felépítése követi ezt a módszertani logikát, alapfogalmi bevezetést követően az első rész a tudásmenedzsment és a technológia viszonyrendszerével foglalkozik, kitérve az innováció és a technológiai menedzsment egyes kérdéseire. A második rész a tudás kompetencia és a technológiai kompetencia szintjén vizsgálja a kérdéskört, kiemelten foglalkozik a különböző technológiai kompetencia definíciók értelmezésével. A leszűrt következtetések célja az elméleti forrásoknak és a kapcsolódó tudásmenedzsment kutatási eredményeknek a jelen cikk témája szemszögéből való felfưzésével megfogalmazni az érintett kutatások lehetséges irányait, különös tekintettel a technológiai kompetenciákhoz kapcsolódó menedzsment kihívásokra napjaink átalakuló technológiai környezetében.

Vizsgálandó kutatási kérdések:

- Hogyan vezethető végig a tudás fogalmától a technológiai kompetenciáig terjedő szakmai ív és ennek fö üzenetei?

- Melyek a témához kapcsolódó, lehetséges további kutatási irányok, javaslatok? 


\section{AZ ALKALMAZOTT MÓDSZERTAN}

Az elemzés során az elméleti tudásmenedzsment fogalmat és megközelítést értelmezzük a tudásmenedzsment és az új technológiák fogalmi kapcsolatának értelmezésével, a kapcsolódó elméleti háttér és releváns kutatási eredmények bemutatásával. A kutatási kérdések feldolgozása során érintjük a kutatásfejlesztés, az innováció és a technológia alapkérdéseit, a kiválogatott mintegy félszáz szakirodalmi forrás (a) áttekintésével, (b) az egyes források fö üzeneteinek rendszerszintű összefűzésével, magyarázatával és értelmezésével.

A technológiamenedzsmenten keresztül összefoglaljuk a gyakorlati alkalmazási nézőpontokat. Ezt követően a tudásmenedzsment és a technológiai kompetencia viszonyát tárgyaljuk, amelynek alapján következtetéseket teszünk. E tárgykörben kitérünk a kompetenciamenedzsment témakörére, majd a tudásmenedzsment és a $\mathrm{K}+\mathrm{F}$ szervezeti menedzsment egyes kérdéseire.

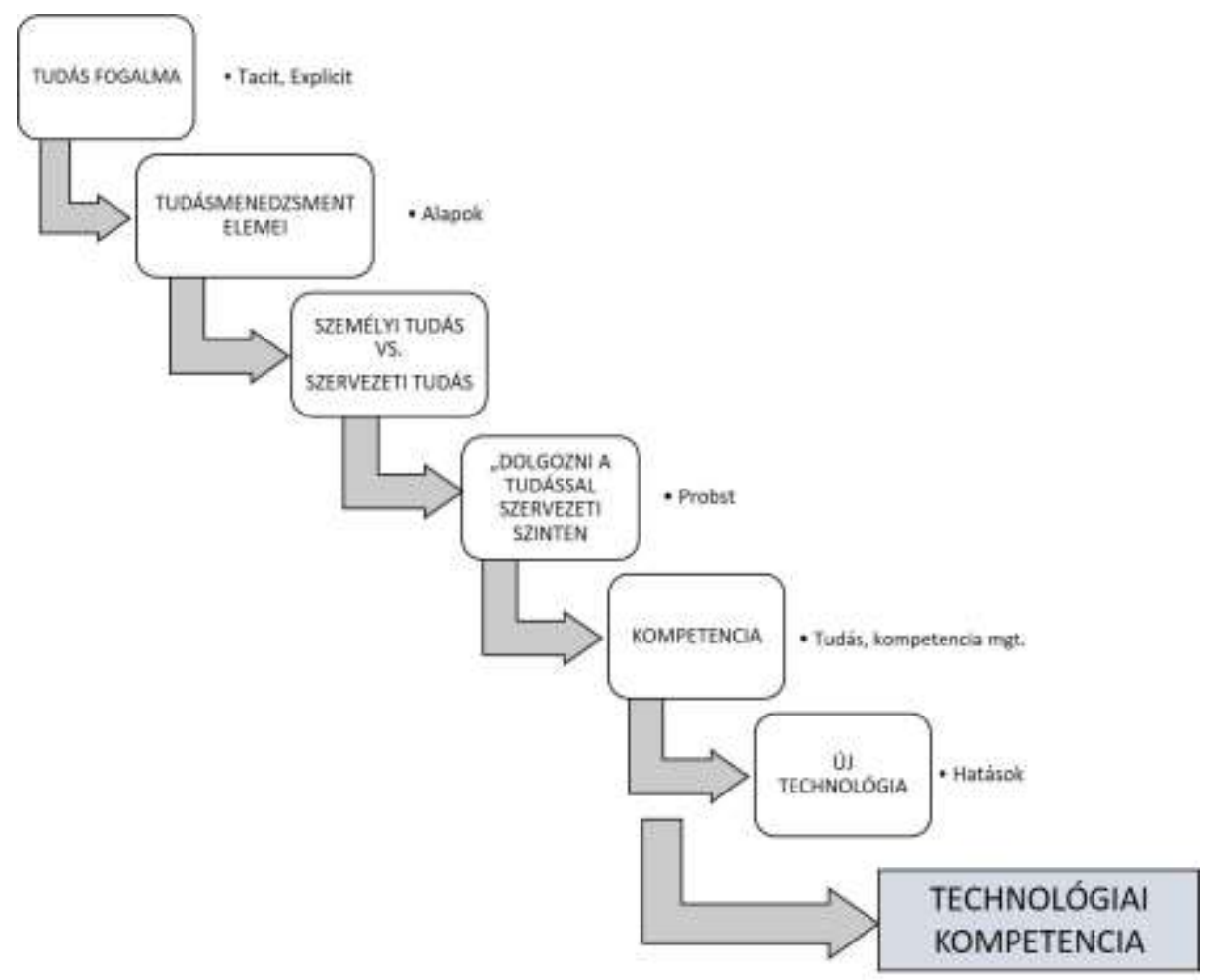

1. ábra A tanulmány struktúráját összefoglaló ábra

Forrás: Saját szerkesztés 
Végül a technológiai kompetencia fogalmának részletes vizsgálatával zárul az elemzés témavonala, amely rámutat a tudásmenedzsment és a technológiai kihívásokra adandó válaszok szoros összefüggésére. A tanulmány módszertani levezetését szemlélteti az 1. ábra.

A kutatás alapvető módszertani megközelítése:

- publikációelemzés,

- kutatási eredményeknek az egymást erősítő felfüzése és ezzel egy logikai lánc felépítése,

- a tudás fogalmától a technológiai kompetenciák kérdésköréig tartó íven végig húzódó szakmai üzenetek feldolgozása és szóelemzés/tartalomelemzés eszköztára segítségével következtetések leszűrése.

\section{A TUDÁSMENEDZSMENT ELMÉLETI BEVEZETÉSE}

\section{Általános fogalmi áttekintés}

A jelen fejezet a tudásmenedzsment egyik tudatosan választott, klasszikus, absztrakt jellegú fogalmával indítja a témakör tárgyalását, majd kettó, a gyakorlatban jól értelmezhető megközelítés mentén mutatja be tudásmenedzsment elemeit, szakaszait.

A tudásmenedzsment egyik fontos fogalmi megállapítása Nonaka és Takeuchi, (1995) szerint: „a tudás igazolt valós hit (justified true belief), a személyes hit valódiságát igazoló dinamikus emberi folyamat". Eszerint a tudás összefüggésben áll a hiedelmekkel, amelyek tudás formájában már tényekkel igazolt alátámasztással rendelkeznek. Ezen igazolt tények gyakran szelektált információkból álló halmazok, amelyeket sajátos álláspontra alakítunk, illetve amelyek az idő során változhatnak is. Bár a tudás nemcsak egy állapotot, hanem magát a megértés folyamatát is magába foglalja, fogalmát tekintve élesen meg kell különböztetni a tapasztalattól. A tapasztalat értelmezése körében említhetô, hogy a tudás egyfajta csoportosítása alapján megkülönböztetünk explicit és tacit tudást. Az explicit tudás az a tudás, amely könnyen leírható és átadható, illetve megszerezhető. Ezzel szemben a tacit tudás már erősen tapasztalat-alapú, azaz az egyénekben és magában a szervezetben lakozik, így nehezen adható át. Fontos jellemzője ugyanakkor a tudásnak, hogy milyen komplexitási szinttel rendelkezik, hiszen egy komplexebb tudásnak nehezebb az átadása (Demeter et al., 2017) Ennek a szempontnak később, a technológiai kompetencia értelmezésekor lesz jelentősége. 
A szervezetek teljesítménye nagyban javítható a tudás megfelelő menedzselésével. A tudásmenedzsment egyik fő feladata így éppen a tudás megőrzése és átadása. Demeter et al. (2017) szerint a tudásmenedzsment három alappillére:

- a tudás létrehozás (creation),

- a tudás megőrzése (retention),

- a tudás átadása (transfer).

A tudás újra termelődését a szervezetben generálódó új tudás adja. A létrejött új tudás megőrzésére olyan eszközt vagy módszert szükséges alkalmazni, amely által az hosszú távon fennmarad. A tudás átadásáról akkor beszélünk, ha például egy szervezeti egység által megszerzett tapasztalat hatással van egy másik szervezeti egység múködésére. A tudástranszfer középpontjában rendszerint mindig az ember, mint tudáshordozó áll, hiszen ezen folyamatnak kulcseleme az egyén kompetenciája, amely maga a transzfer tárgya. Továbbá, a tudástranszferhez a szervezetnek szükséges biztosítani a „hardvert” is, azaz technológiát.

Demeter et al. (2017) hármas felosztásához képest továbbra is finomabb Ganesh (2001) nézőpontja, amely - bár egy korábbi publikáció, de üzenete napjaink technológiai átalakulásai közepette is aktuális a tudásmenedzsmentet öt szakaszra bontja, ennek során a szervezet tanul, reflektál, illetve elfelejt és újra tanul:

- tudásteremtés (creation),

- validálás (validation),

- bemutatás (presentation),

- terjesztés (distribution),

- alkalmazás (application).

Mindezen szakaszok azért szükségesek, hogy a szervezet az alapvetô kompetenciáit kiépítse, fenntartsa és feltöltse. Az öt szakaszon keresztül egy szervezet újra-konfigurálhatja és kombinálhatja a meglévő tudáselemeket és fejlesztheti kompetenciáit. A kutatás-fejlesztési képességek erősítésével pedig képes lesz jobban megfigyelni környezetét, valamint külső technológiák kölcsönzésével és alkalmazásával még inkább katalizálja tudásbázisát, így már új tudást is építhet (Ganesh, 2001).

\section{A szervezeten belüli tudás}

Lee és Chou (2009), Nonaka és Takeuchi (1995) megállapításait viszi tovább egy személyközpontú fogalmi értelmezés szerint, melynek értelmében csak maga a 
személy képes tudást felhalmozni, vagyis egy szervezet csupán a személyek segítségével képes tudást felhalmozni. Emellett, a tudás négy átalakulási folyamata, a szocializáció, externalizáció, kombináció és internalizáció, szintén egyének által motivált és végrehajtott elemek. Egy $\mathrm{K}+\mathrm{F}$ szervezeti csoport számára lényeges, hogy a négy átalakulási folyamat végbe menjen, hiszen ezáltal képesek az egyének új ismereteket generálni és új technológiákat bevezetni. Ezért az egyének tudásteremtő képességei szoros kapcsolatban állnak egy szervezet $\mathrm{K}+\mathrm{F}$ teljesítményével (Lee és Chou, 2009).

Az egyéni tudásokra épített szervezeti tudás logikáját tovább folytatva, 2. ábra (Fehér, 2003 nyomán) egy szervezeten belüli tudás eredetét szemlélteti. Egy szervezetbe bekerülő új munkatárs mindig új tapasztalattal és új tudással érkezik, de valójában egy vállalat rendszerint az egyén speciális képessége, tudása okán alkalmazza a munkavállalókat.

A tudás azonban csak úgy tud kialakulni, ha az adott információ a feldolgozónál cselekvést indít be, tehát a tudás birtoklója képes lesz az információt megfelelően értelmezni, felhasználni és következtetéseket levonni belőle az adott vállalati környezetben. Az egyén tudásátadásának az egyik iránya tehát ebből következően a munkatársai (mint egyének) felé, a másik iránya a szervezet irányába valósul meg. Ez utóbbi az, ahol rejtett tudása formalizálódik és ötleteit megvalósíthatja, ezáltal tudása szervezeti szintre emelkedik, amely már egy, az egyéni tudásnál magasabb szintet jelenít meg.

Az egyén szempontjából nézve, a tudás úgy emelkedik magasabb szintre, hogy keveredik másokéval. A többi munkatárs tudása hasonlóképpen fejlődik tovább, amely létrejövő „komplett” tudás már a szervezet minden tagja számára elérhető és felhasználható tudássá válik. (Fehér, 2003). 


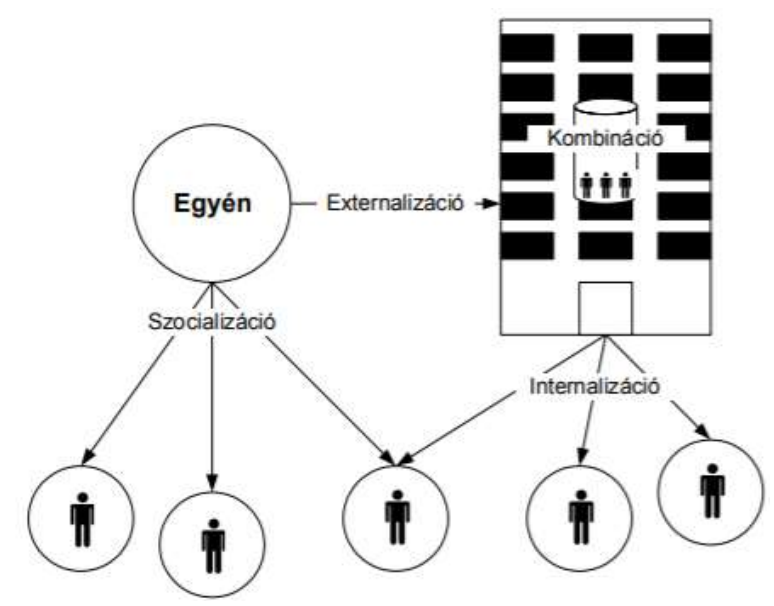

2. ábra Az egyéni tudás beépülése a szervezuetbe

Forrás: Fehér, 2003

\section{A tudás azonosítása, térképezése}

Az előző fejezet a tudás egyik fogalmi értelmezéséből levezetve építette fel az egyéni tudáson keresztül a szervezeti tudás fogalmát, a jelen rész pedig azt járja körbe, hogyan lehet „dolgozni” a tudással.

Bencsik és Für (2015) kutatásai szerint a tudásmenedzsment a vállalat számára azért fontos, mert ezáltal koncentrál az egyének megszerzésére és megtartására, illetve a folyamatos, a vállalati múködést segítő emberi erőforrás fejlesztésére. Ennek során lényeges az egyének tudásának kiaknázása és innovációs készségük naprakészen tartása. Elengedhetetlen az is, hogy a tudásmenedzsment-rendszer kiépítése és múködtetése problémamentesen illeszkedjen a vállalati múködés egészéhez. A tudás használatához kapcsolódó, egyik legismertebb modell Probs nevéhez füződik, amelyben a tudással kapcsolatos tevékenységek nyolc lépcsőn keresztül kerülnek értelmezésre a vállalatok múködése tükrében (3. ábra). 


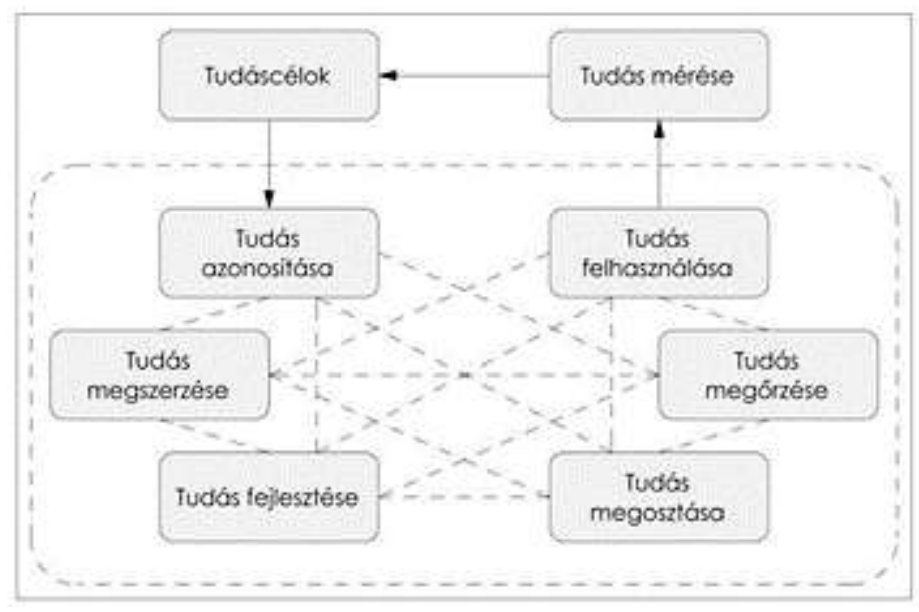

3. ábra Probs-féle modell

idéđi: Bencsik és Für, 2015

A Probs-féle modellt Bencsik és Für (2015) idézte, illetve mutatták be részletesen, kitérve a tudásmenedzsment alapfolyamataira.

A modell szerint a tudásmenedzsment alapfolyamatai a tudás azonosítása, megszerzése, fejlesztése, megosztása, megőrzése és felhasználása.

A tudás azonositásakor a meglévő információk kerülnek feltérképezésre abból a célból, hogy pontosan megértsük a rendelkezésre álló tudást és annak mértékét, illetve azt, hogy az mennyiben felel meg a szervezeti céloknak. A feltérképezés eredménye valamilyen tudáskatalógus, például tudástérkép, amely megmutatja a tudás elemeit és azok pozícióját a szervezetben. A tudáselemek mindazok a tudások, amelyek egyéni és szervezeti szinten rendelkeznek, léteznek vagy hiányoznak, és ez a tudás szükséges a szervezeti feladatok ellátásához.

A tudásmegszerzés célja a hiányzó ismeretek pótlása például új munkatársak toborzásával, külső kapcsolatok felhasználásával, vagy a partnerekkel együttműködve szerzett tapasztalatok és ismeretek révén. Emellett, spontán személyes beszélgetések során is fontos információk kerülhetnek átadásra.

A tudásfejlesztés lényege abban rejlik, hogy egy szervezet sikeres múködése a tudás egyéni felhalmozásától függ, ezért azt folyamatosan fejleszteni kell.

A tudásmegosztás célja a szervezeti szintű tudás növelése, ehhez tudást kell rendelkezésre bocsátani, azt elérhetővé kell tenni, illetve szükséges annak befogadására való hajlandóság. Maga az átvitel akkor történik meg, ha az új ismeret a befogadóban valamilyen magatartás változást idéz elő. 
A tudás megórzése azért fontos eleme a folyamatnak, hogy a szervezet a jövőben is felhasználhassa a megszerzett tudást: ehhez megfelelő rögzítésre, rendelkezésre állásra, tárolásra és frissítésre van szükség.

A fő cél azonban természetszerủen a rendelkezésre álló tudás felhasználbatóvá tétele, a szervezeti célokat támogató módon. Ehhez szükséges kiaknázni felhasználóbarát technológiai megoldások és jól megtervezett informatikai keretek lehetôségeit.

Az előző részekben a jelen cikk tehát, egy tudás fogalomból levezetve, foglalkozott az egyéni tudás kérdéskörével, majd a szervezeti szintű értelmezéssel, valamint bemutatta a tudással kapcsolatos érdemi tevékenységek egy lehetséges felosztását.

Az elméleti megközelítések alapján látható, hogy a tudás fogalma, a tudás menedzselésének elemei, a személyi és a szervezeti szintû tudás kérdése, továbbá a szervezeti tudással „végzett tevékenység” jól egymásra épülő elemek, amelyek egy adott technológiai környezet vagy szervezet esetén megadják a tudásmenedzsment gyakorlati vizsgálatának vagy kutatásainak keretét.

A 4. ábra - köztes következtésként - azt igyekszik kiemelni, hogy a tudás katalizáló hatásmechanizmusa (mint innováció), a tudás épülésének folyamata (mint kutatás-fejlesztés), valamint a szakmai környezet (mint technológia) egymással összefüggő viszonyrendszerben levő elemei a szervezeti tudásmenedzsmentnek, és mint ilyenek, a kapcsolódó vizsgálatokban ezekkel foglalkozni szükséges.

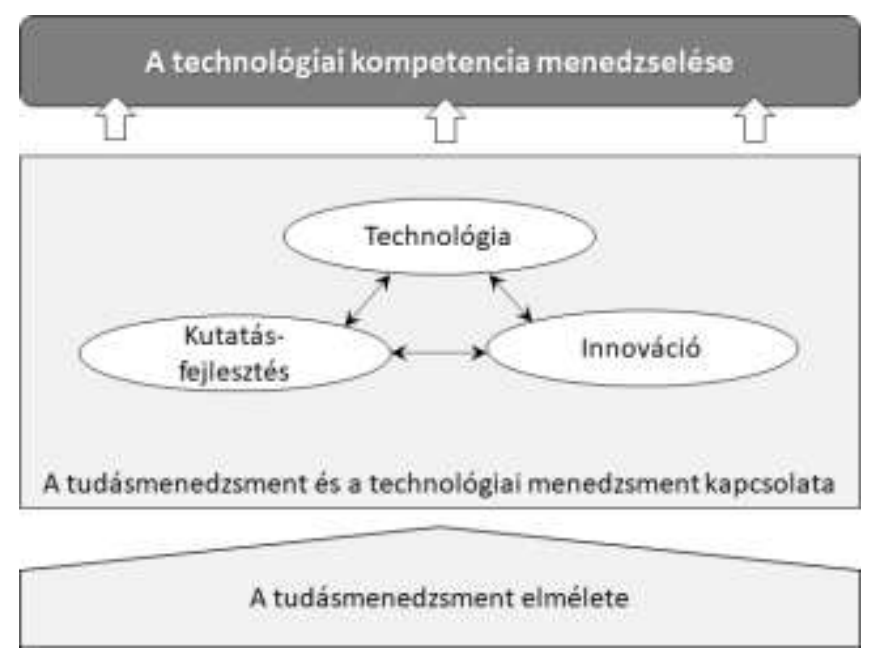

4. ábra A tanulmány követkętetéseinek tematikus felépitése

Forrás: Saját szerkesztés 


\section{A TUDÁSMENEDZSMENT ÉS A TECHNOLÓGIA KAPCSOLATA Kutatás-fejlesztési háttér}

A tudásmenedzsment és a kutatás-fejlesztés, illetve az innováció nagy jelentőséggel bírnak a vállalatok fejlődése során. Elsőként a kutatás-fejlesztéshez kapcsolódóan foglaljuk össze az új tudásokkal kapcsolatos szempontokat.

A $\mathrm{K}+\mathrm{F}$ tevékenység olyan rendszeresen végzett munka, amelynek célja a jelen ismereteink bővítése, beleértve különböző területeket (mint: társadalmi, technológiai ismeretek stb.), és ezen újonnan szerzett ismeretanyagok felhasználása valamilyen új alkalmazások kidolgozására. Klasszikus értelemben háromféle $\mathrm{K}+\mathrm{F}$ tevékenységet különböztethetünk meg: alapkutatás, alkalmazott kutatás és kísérleti fejlesztés. A kutatási tevékenység mindig a meglévő ismeretanyag bővitését, új alkalmazások kidolgozását célozza, valamilyen tudományos bizonytalanság feloldása érdekében; a témát részletesen elemezte Kajati (2013).

A háromféle kutatás-fejlesztési tevékenység erősen eltér a kapcsolódó tudások szemszögéből, ezért a cikk jelen pontján röviden összefoglaljuk a három $\mathrm{K}+\mathrm{F}$ ilyen nézőpontú lényegét.

$\mathrm{Az}$ alapkutatás célja új ismeretek szerzése kísérleti és elméleti úton. Jellemzője a tudásbővítés, megfigyelhetô jelenségek és tények segítségével. Viszont nem célja eredmények konkrét alkalmazásának és felhasználásának, azaz gyakorlati jellegú tudásnak a vizsgálata. Az alapkutatások esetében fontos, hogy már ismert vagy a jövőben felmerülő problémákra a szerzett tudás elvi megoldás lehetőségét kínálja. A legtöbb esetben egyetemeken, kutatóintézetekben végeznek alapkutatásokat, amelyeknek közvetlen nincs üzleti haszna, viszont számos terméknek és alkalmazott kutatásnak adják az alapját, adott esetben tudás-oldani megalapozását is. Az alkalmazott kutatás feladata szintén új tudásanyag megszerzésére irányuló kutatás, viszont az alapkutatással szemben célja, hogy a megszerzett tudásanyag felhasználható legyen új termékek vagy új szolgáltatások kifejlesztéséhez. Szerepe, hogy hozzájáruljon a jelenlegi folyamatok és termékek vagy szolgáltatások javulásához úgy, hogy a gyakorlat által meghatározott kérdésekre keresi a válaszokat. Vagyis az alkalmazott kutatás már szorosabban kötődik a gyakorlati tudásokhoz, miközben elméleti alapon hoz létre új tudásterületeket és tudásszinteket. A kísérleti fejlesztés már konkrétan a gyakorlati alkalmazás körében járul hozzá a termékek továbbfejlesztéséhez vagy a folyamatok, szolgáltatások javulásához. Az általa felépített tudást, az alkalmazott módszereket és eredményeket ezt követően tervekbe vagy megvalósítási eljárásokba foglalva használják fel. 


\section{A tudásmenedzsment és az innováció}

A tudásmenedzsment és a $\mathrm{K}+\mathrm{F}$ viszonyának taglalása mellett kell kitérni a tudásmenedzsment és az innováció relációjára.

Fontos, hogy az innováció nem mindig jár azt megelőző $\mathrm{K}+\mathrm{F}$ tevékenységgel (pl.: Facebook), ugyanakkor a két fogalom szoros kapcsolatban áll egymással. Ezen a ponton hivatkozzuk az innováció és a technológiai innováció definíciójának rövid ismertetését egy korábbi, nagy hivatkozással rendelkező, klasszikus, ám napjaink technológiai változásai közepette is relevánsforrás alapján. Drucker (1986) az innovációval kapcsolatos publikációjában így fogalmazott: „az innováció szervezett, tervezett és célszerű tevékenység, melynek során a vállalatok igyekeznek új, a meglévőktől különböző értéket létrehozni, új és a meglévőktől eltérő igényeket kielégíteni, vagy a meglévő forrásokat új módon, nagyobb nyereséget hozó formában átcsoportosítani”. Ez egy általános jellegú definíciónak tekinthető, amely ugyanakkor napjainkban is megállja a helyét. A következőkben a technológiai innováció fogalmának értelmezéséhez technikai orientációjú definíciót hivatkozunk, a Frascati kézikönyvből.

A nemzetközileg is gyakran hivatkozott Frascati Kézikönyv alapján a technológiai innováció: „minden olyan tudományos, műszaki, szervezeti, pénzügyi és kereskedelmi jellegű tevékenység, beleértve az új ismeretanyagba történő befektetéseket is, amely ténylegesen, vagy szándék szerint múszakilag új vagy továbbfejlesztett termékek, eljárások és szolgáltatások megvalósításához vezet" (idézi: Kline és Rosenberg, 1986).

Bencsik és Für (2015) kutatásaik során vizsgálták az innováció és a tudásmenedzsment szimbiózis kapcsolatát, a két fogalom közös elemeit, úgymint a rendszer, ember-ember kapcsolat, fejlődés, visszacsatolás.

Továbbá, kutatásaik vizsgálták az ún. 5. generációs innovációs modell és a (Probst-féle) tudásmenedzsment modell közös jellemzőit, amelyeket a következőképpen említenek:

- stratégiai gondolkodás - rendszerszemlélet,

- ember-ember kapcsolat - hálózatépítés,

- intellektuális képességek,

- tudásátadás - tudáshálózat.

Ezek alapján a szerzők által javasolt tudásmenedzsment fókuszterületek a következők:

- tudáscél - kutatási fókusz,

- tudásazonosítás - munkatársak, 
- tudásszerzés - információ,

- tudásfejlesztés - innovációs ötletek kialakítása,

- tudásmegosztás belül - innovációs ötlet kidolgozása,

- tudásmegosztás kívül - hálózatépítés,

- tudáshasznosítás - prototípus elkészítése (fejlesztése),

- tudásrögzítés - know how, találmányok, szellemi termékek kezelése,

- tudásellenőrzés - piaci visszajelzés.

A jelen rész az innováció szemszögén keresztül közelítette meg a tudásmenedzsment témakört. Az előzőekben felsorolt fókuszterületek az innováció egyes fázisai és a tudásmenedzsment folyamat szakaszai kapcsán is jól értelmezhetők; a két nézőpont összekapcsolható.

A cikk az előző részeiben a tudás és a $\mathrm{K}+\mathrm{F}$, valamint a tudás és az innováció kettősén keresztül füzte fel a megvizsgált közlemények fő konklúzióit és tartalmazott elemző kiegészítéseket. A következőkben a harmadik viszonyrendszer, a tudás és a(z új) technológiák relációja kerül összefoglalásra.

\section{A tudásmenedzsment elhelyezése a technológiák kontextusában}

A korábbiak alapján, hasonló szimbiózis mentén vizsgálható a technológiák kérdésköre és a tudásmenedzsment. A kutatás-fejlesztési tevékenységek nem választhatók el a technológiai fejlődéstől, amelyhez szükség van mindaz egyének, mind a szervezet tudására, kompetenciájára.

A technológia szó eredete visszavezethető a következő két szóra: a görög „techné”, ami mesterséget jelent és a „logosz”, amely ismeretet/tant szavakból ered. Itt is látszik, hogy az ismeret, mint a tudás egy eleme és a technológia szó, elnevezésükben is egymással összetartozó fogalmak.

Pataki (2005) meghatározása alapján: „A technológia szükségletek kielégítését lehetôvé tevő szaktudás- és eszközrendszer.” A forrás a tudásmenedzsment egyik legalaposabb hazai feldolgozása, amelynek az elvi fogalmi megalapozást segítő üzenetei és következtetései napjainkban is aktuálisak, ezért a cikk jelen fejezeteiben alapvetően támaszkodunk erre a forrásra.

A technológia ezen definíciójából kiindulva, ismételten eljutunk az új tudások iránti igény témaköréhez, különös tekintettel a világban jelenleg folyó igen jelentős technológiai váltásra. A technológiához köthetô (elméleti és gyakorlati) tudás kapcsán fontos elkülöníteni, hogy a mindennapi tudásnak a valóságos tudás alapszintjét nevezzük, amellyel a világban tájékozódunk. Ez a tudás az oktatás különbözô szintjein és iskolán kívüli tanulással megszerezhető. Emellett, a 
szakjellegú tudás (szaktudás) már magasabb szintje a valóságos tudásnak, amelyet leggyakrabban szervezett oktatás és képzés keretei között tudunk elsajátítani. Bár a szaktudást a mindennapi tudással kiegészítve alkalmazzuk, az értelmezés alapján, a mindennapi tudás nem része a technológiának. Továbbá, fontos azt is kiemelni, a „szaktudás- és eszköz” szópár arra is utal, hogy a tevékenységek végzéséhez elengedhetetlen ismerni a tevékenység módját, és rendelkeznünk kell a hozzá szükséges eszközökkel. A technológia tehát egy „tudásrendszert” képez, amelynek elemei kompatibilisek kell legyenek egymással.

Egy adott technológia fejlesztése jellemzően a tudományos alapokra támaszkodik, de olyan tapasztalati tudás is a részét képezheti, amelyre nem ismerjük a tudományos magyarázatot, de még használjuk mert a gyakorlatban múködik (Pataki, 2005).

Érdekes nézőpont a technológiai terület és az innovációs együttes kérdésköre is. A technológiai innováció kulcsfontosságú a vállalatok számára a tartós versenyelőny megtartásához. Ez egyfajta dinamikus képességnek is felfogható a fennmaradásért, főként a tudásalapú és csúcstechnológiás iparágakban. Ennek érdekében esszenciális értékkel bír a tudásmenedzsment, a szellemi tôke és a szervezeti tanulás, amelyek a technológiai előnyt képezhetik. A dinamikus képesség fenntartásához megállapítható, hogy egy vállalat önmagában nem lesz sikeres. A témát Castro (2015) vizsgálta, és rámutatott, hogy a technológiaorientált vállalatoknak is szükségük van külső kapcsolatokra és hálózatokra, hiszen a hiányzó tudásterületeket folyamatosan ki kell egészíteniük.

\section{A technológiák menedzselésének megközelítései}

Ahhoz, hogy a tudás szerepét a technológiák kapcsán jobban megérthessük, célszerű operatív szempontból megtenni a technológiák tipológiai áttekintését, Pataki (2005) könyve nyomán.

A technológiák szorosan kapcsolódnak a tudásalapú versenyképesség kérdéséhez, hiszen egy-egy új technológia nem elválasztható a kapcsolódó új tudásoktól. A technológiák többszempontú klasszifikálása segít megérteni az egyes technológiák eltérô kompetenciai és tudásigényeit.

A termék (fizilkai termék vagy szolgáltatás) lényegébez való kapcsolódás tekintetében a technológiák az alábbi módon csoportosíthatók:

- magtechnológiák (core technologies),

- kiegészítő technológiák (complementary technologies),

- periférikus technológiák (peripheral technologies). 
A magtechnológiák (core technologies) alkalmazásával a termék lényegét hozzuk létre, amely az adott technológia nélkül nem létezhetne (ebben a formájában). Tehát, a magtechnológiák a termék alapfunkciójához szükségesek. A legtöbb vállalat ezekkel a magtechnológiákkal foglalkozik $\mathrm{K}+\mathrm{F}$ tevékenységei során. Ebből eredően a versenyelőnyt megalapozó tudásháttér rendszerint beépül a megtechnológiába, a tudás védelme és kiaknázása döntő versenytényező. A kiegészítő technológiákra (complementary technologies) szintén szükség van a termékekhez, azonban „csak” kiegészíto szerepet játszanak, mivel ezen technológiák az alapfunkciókat kiegészítő, értéknövelő funkciók létrehozásához szükségesek. Vagyis, szerepük az ügyfelek számára a többlet-tudás révén többletértéket nyújtani. E tekintetben a kiegészítő technológiák jelenthetik például a piaci megkülönböztetés alapját is, miközben kifejezetten szakma-specifikus és általában specialista tudásokat igényelnek. A periférikus technológiák (peripheral technologies) alkalmazása által létrehozott termékfunkciók nem feltétlenül szükségesek a termékhez vagy szolgáltatáshoz, tudásalapú hátterük változatos lehet. Alkalmazásuk azonban tovább növelheti a termék piaci értékét.

A piaci versenyképesség növelése szempontjából az alábbi három csoportba sorolhatók a technológiák:

- alaptechnológiák (base technology

- kulcstechnológiák (key technology)

- iramdiktáló technológiák (pacing technology)

Az alaptechnológiák (base technology) az adott szakterületen folytatott tevékenység alapjait jelentik. A verseny sikere szempontjából ezen tudások és kompetenciák birtoklása nem kritikus, hiszen szinte minden versenytárs rendelkezik velük vagy könnyen hozzájuthat. A kulcstechnológiák (key technology) azonban a legnagyobb hatással bírnak a versenyképességben. Aki rendelkezik velük, az előnyhöz juthat, viszont aki nem, az könnyen hátrányba kerülhet. Szerepük és tudás-oldali megközelítésük hasonló, mint a magtechnológiáké. Az iramdiktáló technológiák (pacing technology) olyan technológiák, amelyek a fejlődési szakasz elején tartanak, de magukban hordozzák annak lehetőségét, hogy későbbiekben pozitív hatást gyakoroljanak a verseny kimenetelére. Az elnevezés abból származik, hogy a kialakulásukkal diktálják a verseny iramát, sokszor egy-egy termék vagy technológia áttörő típusú tudásháttere jellemzi őket. 
A különböző technológiai csoportok irányításához a technológiai menedzsment szakterülete járul hozzá, amely Pataki (2005) szerint nem más, mint „az a keresztfunkcionális tevékenység, amely a szervezet eredményes és hatékony múködésének szolgálatába állítja a technológiát.” A szerző ugyanakkor kiemeli, hogy a technológiai menedzsment nemcsak az üzleti siker eléréséhez fontos, ha például egy nonprofit szervezet számára nem a profit a releváns cél, azonban a sikeres és eredményes múködéshez szintén szükség van technológiai menedzsmentre. (Pataki, 2005) Mint a technológiai menedzsment szoros kísérô területe, a tudásmenedzsment ugyanúgy jelenik meg a for profit és a nonprofit szervezetek körében. A „keresztfunkcionális” (cross functional) megfogalmazás azt jelenti, hogy maga a tevékenység átnyúlik funkcionális határvonalakon, vagyis keresztezi azokat. Tehát, különböző szakterületű emberek dolgoznak együtt egy adott projekt kapcsán. Ezzel hasonlatos a tudásmenedzsment azon feladatköre, amely az adott probléma megoldásra vagy akár az egész vállalat hosszútávú stratégiájához hozzárendeli a „megfelelő” tudással rendelkező embereket csoportokba, hogy a különböző funkcionális feladatokat ellássák.

Pataki (2005) vizsgálatai nyomán a technológiaimenedzsment az alábbi fontos kérdésekre keresi a megoldást:

- Hogyan hangoljuk össze a technológiát a cég átfogó stratégiai céljaival?

- Hogyan vezessük be, illetve cseréljük le gyorsabban és hatékonyabban a technológiákat?

- Hogyan becsüljük fel, értékeljük ki hatékonyabban a technológiát?

- Hogyan vigyük végbe a technológiatranszfert?

- Hogyan csökkentsük az új termékek kifejlesztésének időigényét?

- Hogyan menedzseljünk nagy, összetett, interdiszciplináris és interorganizációs projekteket és rendszereket?

- Hogyan menedzseljük a technológia szervezeten belüli használatát?

- Hogyan javítsuk technikai szakembereink eredményességét?

Ezen kérdéseket megfigyelve, akár a 'tudás' szót is behelyettesíthetnénk a 'technológia' helyére, hiszen szinte ugyanezeket a kérdéseket járja be a tudásmenedzsment is. A technológia és a technológiamenedzsment elemzésének összegzéseként elmondható, hogy nagymértékben fellelhető kapcsolat a tudásmenedzsmenttel, hiszen a technológia is magába foglalja azt a személyt, aki a kívánt tudással rendelkezik. Ebből arra következtethetünk, hogy a kutatásfejlesztés és a tudásmenedzsment között is szignifikáns kapcsolat áll fenn, hiszen 
a kutatás-fejlesztési szervezeti funkció magában foglalja a technológiával kapcsolatos korábban ismertetett meghatározásokat, illetve maga a technológiaimenedzsment tevekénységek is átfedésben állnak a $\mathrm{K}+\mathrm{F}$ területtel.

A cikk előző részei részletes összefoglalót tartalmaznak az innováció, a technológia és a kutatás-fejlesztés hármasára építve a tudásmenedzsment releváns kapcsolódásairól.

A következő fejezet zárja az összeállítás logikai sorát a kompetencia szintű értelmezéssel, amely okfejtésnek a konkrét kimenete a technológiákkal kapcsolatos következtetések megfogalmazása, további, a témához kapcsolódó kutatások megfogalmazása céljából.

\section{TUDÁS KOMPETENCIA VS. TECHNOLÓGIAI KOMPETENCIA}

\section{A kompetenciamenedzsment, mint háttér}

A kutatás-fejlesztés és a tudásmenedzsment kapcsolatának feltárása során szükséges értelmezni a kompetencia és a kompetenciamenedzsment összefüggését. A kompetencia illetékességet, alkalmasságot és szakmai hozzáértést jelent. Berényi (2012) szerint egy ember kompetenciája lényegében a képességei és készségei összessége, amelyekkel tud reagálni a vele szemben támasztott követelményekre. Emellett, a kompetenciamenedzsment feladata, hogy meghatározza a releváns kompetenciakövetelményeket, és megtalálja a kielégitésükhöz szükséges emberi erőforrásokat. A vállalatok üzleti modelljeinek kialakítása a technológiai kompetenciák mentén népszerû. A legtöbb szervezet alkalmazza a kompetencia vizsgálatot az emberi erőforrás menedzsment területén. Az elmúlt húsz évben rengeteg tanulmány foglalkozott kompetenciák természetével, azonban nem tisztázódtak a fóbb kérdések, amelyekből az elmélet kiindult. A kompetenciák természetére és dinamikájára, illetve összefüggéseire egyértelmúen jelen vannak. Másrészt a kompetenciák diagnosztizálásának kérdésköre továbbra is nyitott, hiszen a múltbéli tapasztalatok alapján nem feltétlen következtethetünk a jövőbeni szükségletekre. A konkrét kompetencia meghatározása egy adott, vizsgált területen nehéz (Kashirin, 2018). 


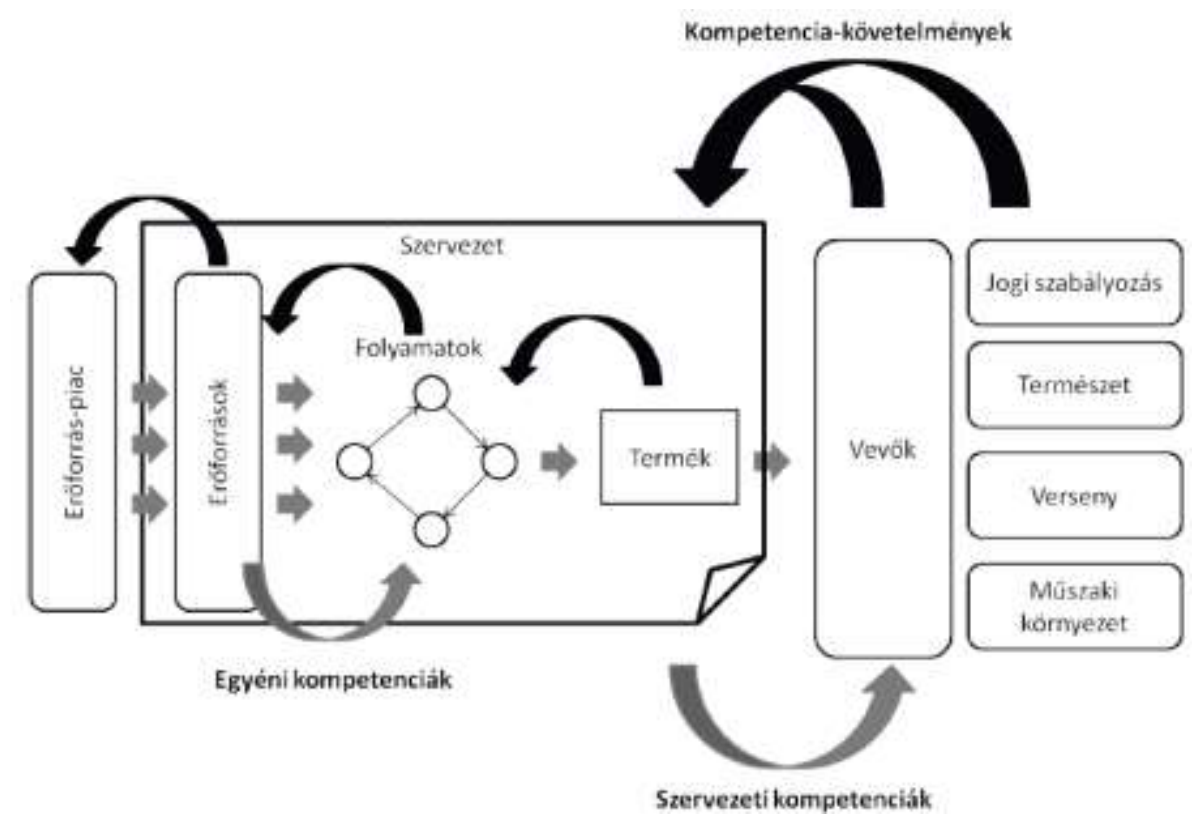

\section{5. ábra Szervezeti kompetenciák}

Forrás: Berényi, 2012

Berényi (2012) kutatásai nyomán a szervezeti szintű kompetencia szemléltetésére az 5. ábrán levő modellt definiálta, ahol a fő kompetenciakövetelmények külső forrásból jönnek, amelyekhez kell igazítani a szervezetet.

A kompetencia tehát tudáson, tapasztalaton és az értékeken alapuló, olyan általános képesség, amelyet az adott személy tanulás során fejleszt ki magában. Ezek alapján a kompetenciát négy összetevő alkotja: a tudás, készség(ek), attitűdök, személyiség és motivációk. A kompetencia jellegek és a tudásmenedzsment elemei szoros összefüggésben állnak egymással. A személyiségjellemzők alapján megállapítható, hogy az adott személynek például milyen hajlandósága van a tudásmegosztás, vagy annak megőrzése felé.

Emellett, a tudásmenedzsment egyéb elemei is hatással vannak a kompetenciára, hiszen például a kompetenciamérés és személyre szabott fejlesztések fontos területérôl van szó. A magkompetencia a szakismeretekből és a technológiákból összeálló, versenyelőnyt adó speciális szaktudás. Ennek a képességnek a birtokában az adott vállalat bizonyos dolgokat el tud végezni, tehát egy olyan szakértelmet birtokol, amit a versenytárs nem (Pataki, 2005). Ezért a szervezetek számára fontos a magkompetencia azonosítása, és annak kihasználása a piaci versenyben. Ezzel a szervezet tud rendelkezni, beleértve a szervezetet alkotó egyéneket és az infrastruktúrát, technológiát. A $\mathrm{K}+\mathrm{F}$ tevékenység ugyancsak 
szorosan kapcsolódik ehhez a területhez, hiszen a magkompetenciát meg kell tudni teremteni, illetve esetlegesen tovább is kell fejleszteni. Ehhez járul hozzá a tudásmenedzsment, illetve hasonlóan a kompetenciamenedzsment is. A különböző kutatás-fejlesztéssel foglalkozó szervezeteknek meg kell találni azokat a tényezőket, amelyekkel sikerül előnyeiket megteremteni és kihasználni azt. Ehhez szükséges alkalmazni irányítási mechanizmusokat, mint a tudásmenedzsment szakterületének a megfelelő vállalati menedzsment struktúrába történő beillesztése.

\section{Tudásmenedzsment a szervezeti $\mathrm{K}+\mathrm{F}$ menedzsment körében}

Yang et al. (2007) kutatásai során megállapították, hogy a tudásmenedzsment multidiszciplináris sajátosságokkal rendelkezik. Emellett, a tudás, a tudásfejlesztés minden szakaszában kulcsszerepet kell kapjon, mind a kapott tudás tekintetében, mind a szervezet funkciónak javításában. Egy kutatás-fejlesztési tevékenység során a tudásmenedzsment elemei, mint a tudástranszfer sikeressége kérdésessé válik, ha a $\mathrm{K}+\mathrm{F}$ projekten belül több a tacit alapú tudás. Ez esetben a tudástranszfer könnyebb, ha a tudás explicitebb, tagoltabb, miközben a tacit tudás átadása kétértelműséget okozhat a befogadónál (Akram et al., 2011).

A tudásmenedzsment vizsgálata során Hatchuel et.al. (2002) megkérdőjelezte a tudásmenedzsment fogalmi körét, miszerint mennyiben van szükség a tudásmenedzsmentre, hiszen a hétköznapokban szerzett tudással oldjuk meg a problémákat. Kutatásai szerint egyes intézmények és vállalatok nagyon kevés figyelmet fordítanak a tudásmenedzsment fontosságára. Megemlíti, hogy amikor egy cég jobban teljesít, annak egyik oka lehet, hogy egy szervezeten belül megosztják és átadják az egyének, illetve a csoportok a tudását, emellett új készségeket sajátítanak el és azokat a jelenlegivel újra egyesítik.

A tudásmegosztás azonban nem mindig magától értetődő, gyakran egy szervezet tagjai nem törekednek tudásuk megosztására másokkal. A munkatársak sokszor attól tartanak, hogy ezáltal gyengül a pozíciójuk, és ha átadják tudásukat, akkor nélkülözhetővé válnak. Emellett számos akadályozó tényező léphet fel mind a szervezeten belül, mind pedig a szervezeten kívül is (Keczer, 2016).

Parikh (2001) kutatásában Rousselés Erickson (1995) szerzőket idézte, miszerint a K+F egyetlen valódi terméke az maga a tudás. Emellett szintén idézte a Pegels és Thirumurthy (1996) szerzőpárost, akik úgy találták, hogy a technológiai erő fejlődése és a $\mathrm{K}+\mathrm{F}$ erőfeszítésekből származó tudás felhalmozódása meghatározta a cégek teljesítményét a high-tech iparágakban. Továbbá, az innováció-orientált $\mathrm{K}+\mathrm{F}$ folyamatok olyan tudásintenzívek, amelyek nemcsak a 
meglévő tudást használiák fel, hanem új tudást is létrehoznak, ami versenyelőnyt biztosít a cég számára. A $\mathrm{K}+\mathrm{F}$ szempontjából kritikus tudás számos forrásból származik; továbbá két dimenzióban azonosíthatók és kategorizálhatók a fó források: a belső és a külső, valamint a hallgatólagos (tacit) és az explicit tudás. A belső források a szervezeten belül vannak, és általában a menedzsment ellenőrzése alatt állnak. A belső forrásokból származó ismeretek többnyire saját tulajdonúak, és védeni kell őket. A külső források a szervezeten kívül találhatók, és más entitások, például versenytársak, szövetségi partnerek, ügyfelek és kormányzati szervek ellenőrzése alatt állnak. A külső forrásokból származó tudás nyilvános lehet, ezért mindenki számára elérhető.

A $\mathrm{K}+\mathrm{F}$ sikeréhez a tudást minden kritikus forrásból össze kell gyújteni. A megfelelő kombináció azonban az adott projekttől függ, a $\mathrm{K}+\mathrm{F}$ projekt típusa (termék vagy folyamat), jellemzői (komplexitás, innovatív képesség, alkalmazás stb.) és fázisai (ötletgenerálás, prototípus-fejlesztés, megvalósítás stb.) mind befolyásolják az összegyújtött tudást. A $\mathrm{K}+\mathrm{F}$ tudás kezelésének képessége végsősoron nagymértékben függ a tudásforrás típusától (Mihir, 2015).

\section{A technológiai kompetencia szerepe}

Arballo et al. (2019) értelmezése szerint a technológiai kompetencia egyértelmú összefüggésben van a tudásmenedzsment területtel. A technológiai kompetenciák felfoghatók úgy, mint a különböző szakterületeken alkalmazott konkrét szakmai teljesítmény. A szakmai teljesítmény kapcsán kétféle kompetenciára van szükség, a technológiai kompetenciák és szakterület-specifikus kompetenciák. Ezért amikor egy olyan szakmai feladat kerül elő, amely technológiai kommunikációt igényel, valójában mindkét típusú kompetenciára szükség van, mindegyikre a maga saját múködési logikája mentén. A technológiai kompetenciák konkrét ismeretekkel jelennek meg a különböző szakmai területeken. Ezért a technológiai kompetenciák értelmezhetők transzverzálisan információ, tudás, kommunikáció és intelligencia feldolgozására bármely szakmai területen. A szakmai teljesítményhez kapcsolódóan meg kell jegyezni, hogy a technológiai kompetencia szimbiotikusan múködik más szakterület-specifikus kompetenciákkal, az egyik kompetenciatípus nem választható el élesen a másiktól. Ebben az értelemben technológiai a kompetenciák a szakmai kompetenciák „modellezőiként” jelennek meg.

A technológiai kompetencia fogalmi megfogalmazása és azonosítása ezért lényeges a vállalkozások számára a megfelelő képzési és tudásértékelési javaslatok 
kidolgozásához. A következőkben kiindulásként Arballo et.al (2019) munkájára támaszkodunk e tekintetben.

Arballo et al. (2019) vizsgálta a technológiai kompetencia értelmezését a szakirodalomban, és arra a következtetésre jutott, hogy a hivatkozások 56\%-a ipari értelemben, 37\%-a képzési értelemben, $2 \%$-a pedig gazdasági értelemben használja a kifejezést. Az ipari megközelítés az ipari esettanulmányokra orientált kutatást képviseli és a termelő szektor, az adminisztratív tudományokkal, a marketinggel és a vállalkozással kapcsolatos fejlesztési koncepciókból származik. Az oktatási megközelítéshez kapcsolódó tanulmányok a pszichológiai és az oktatási területről származnak, értelmezésük elsősorban a tanítási-tanulási stratégiák kidolgozására irányul, ahol a legtöbb a kutatásban a cél a képzők technológiai tudásszintjének javítására irányul. A gazdasági-üzleti megközelítés láthatóan az ipari megközelítéshez köthetô, de ez egy új kutatási irányzat, amelyet az a tény különböztet meg, hogy a technológiát úgy tekintik, mint elsősorban pénzügyi növekedési stratégia a szervezetek számára.

Esetünkben az ipari megközelítés a releváns, ezért a továbbiakban ezt részletezzük tovább.

A technológiai kompetencia kifejezés meghatározásának Marc Giget volt az úttörője az ipari területen belül. Giget a 80-as években elemezte a japán ipart és lehetőségeit. Eredetileg egy fa struktúra segítségével, szimbolikusan magyarázta a technológia funkcióját az iparban (Giget, 1984), majd 1997-ben fogalmazta meg a technológiai kompetencia kifejezést (Giget, 1997), amely mára benchmark lett, több mint 70 kutatási munka számára. Giget definíciója három fő aspektust integrál, amelyeket tudásnak nevezünk. Az egyes aspektusok leírják, hogyan kell megalapozni, hogyan kell elóállítani és hogyan kell eladni a technológiai kompetenciát. Mindezt nem csupán önállóan, a technológiára fókuszálva teszi, hanem belehelyezi az értelmezést a teljes ipari ciklusba, és a külső, illetve belsô vállalati folyamatokba.

Arballo et al. (2019) áttekintő kutatása nagyon széles képet a technológiai kompetencia kifejezésről, a jelen tanulmányban ezek közül hivatkozunk néhányat, mint az ipari értelmezés számára releváns megközelítést (1. táblázat). 
1. táblázat. A technológiai kompetencia ipari orientációjú értelmezése

\begin{tabular}{|c|c|}
\hline Szerző & Definíció - a technológiai kompetencia: \\
\hline Morcillo, 1997 & $\begin{array}{l}\text { Három elem integrálásának eredménye: vízió, } \\
\text { erőforrások és képességek, amelyek a folyamatos } \\
\text { tanulás visszacsatolási folyamatait alapozzák meg, } \\
\text { egyénileg vagy kollektíven jön létre, egyben építenek } \\
\text { az adott szervezetet érintố különböző technológiai } \\
\text { trendekre. }\end{array}$ \\
\hline Tyler, 2001 & $\begin{array}{l}\text { Egy vállalat technikai eszközeinek halmaza, valamint } \\
\text { a kompetenciák a vállalat képességeinek összesége. }\end{array}$ \\
\hline $\begin{array}{l}\text { Prahalad \& Hamel, } \\
1994\end{array}$ & $\begin{array}{l}\text { Három meghatározott elem integrálásának } \\
\text { eredménye: a stratégiai kihívás, technológiai } \\
\text { erőforrások és dinamikus képességek, ami azt } \\
\text { jelenti, hogy a tudást meg kell tudni teremteni, } \\
\text { előállítani és eladni. }\end{array}$ \\
\hline $\begin{array}{l}\text { Prahalad \& Hamel, } \\
1990\end{array}$ & $\begin{array}{l}\text { Kollektív tanulás a szervezetben, amely épít a } \\
\text { különböző gyártási technikákra és integrálja az } \\
\text { elérhető technológia hátteret. }\end{array}$ \\
\hline Nieto, 2004 & $\begin{array}{l}\text { A technológiai innováció, amelynek áramlása } \\
\text { lehetővé teszi a folyamatok leírását a technológiai } \\
\text { tudás generálásához. }\end{array}$ \\
\hline Hlupic, 2002 & $\begin{array}{l}\text { Egy szervezet tudástőkéje, amely a termelési } \\
\text { (technikai) apparátus különböző szintjein múködik. }\end{array}$ \\
\hline Anagnostopoulos, 1998 & $\begin{array}{l}\text { Tudás és készségek összessége, amely lehetővé teszi } \\
\text { a különböző technológiák megértését, elemzését és } \\
\text { az azokról való döntést. }\end{array}$ \\
\hline Bell \& Pavitt. 1993 & $\begin{array}{l}\text { Erőforrások, amelyek szükségesek a beruházások, } \\
\text { folyamatok és a termelés, a termékek } \\
\text { megszervezésének, eszközöknek a fejlesztésével } \\
\text { kapcsolatos menedzsment tevékenységekhez. }\end{array}$ \\
\hline Vallejo et. al, 2016 & $\begin{array}{l}\text { A szervezet képessége technológiáinak hatékony } \\
\text { kezelésére és folyamatainak menedzselésére annak } \\
\text { érdekében, hogy versenyképesen tudja fejleszteni } \\
\text { gyártási folyamatait. }\end{array}$ \\
\hline $\mathrm{z}, 2003$ & $\begin{array}{l}\text { Az új technológiákból származó lehetôségek } \\
\text { ismerete a tudás további fejlesztése érdekében. }\end{array}$ \\
\hline
\end{tabular}

Forrás: Saját szerkesztés Arballo et. al (2019) nyomán

Jól látható, hogy tartalmát tekintve, mindegyik definíció érinti nemcsak a technikai, azaz eszköz jellegú nézőpontot, hanem a humán, azaz a klasszikus tudásmenedzsment oldali szempontot is. Vagyis, a technológiai kompetencia 
vállalati értékelésénél, elemzésénél a humán és a technikai jellegú nézőpont együttesét kell vizsgálni. Nem utolsó sorban Kosimov és szerző társai (2021) szerint nem szabad elhanyagolni a versenyképes szakemberek képzését a felsőoktatásban, hiszen kritikus értékkel bír a technológiai kompetencia a szakember képzésben. Meghatározásuk szerint a technológiai kompetencia nem más, mint a technológiai ismeretek és készségek, illetve képességek alapja. A képzéshez három kompetencia szintet határoznak meg:

- Integratív kompetencia

- Az a képesség, hogy integráljanak és kiegészítsék egymás képességeit, készségeit

- Szociálpszichológiai kompetencia

○ Emberi tulajdonságok megértéséhez szükséges ismeretek, motiválás, kommunikáció és empátia

- Vezetői kompetencia

○ Döntéshozatal, adatgyüjtési módszerek és emberekkel végzett munka stb.

Tulajdonképpen szükség lehet egyfajta együttmúködésre is a vállalatok és az akadémia között, egymást segítve a szükséges kompetenciák eléréséhez és létrehozásához.

Arballo munkája jó áttekintést adó elemzés, amely mind a korábbi, mind a jelenlegi definíciókat vizsgálta. Látható ugyanakkor, hogy az egyes definíciók eltérő módon közelítik meg a technológiai kompetencia fogalmának értelmezését; visszatérô elem a technológiai tudás, a technikai erőforrások köre, de van olyan is (pl. Morcillo, 1997), amely éppen a technológiai változások, trendek oldaláról közelít annak ellenére is, hogy ez történetesen egy régebbi forrás. Vallejo (2016) a technológiai kompetenciák és a szervezeti képességek összefüggő jellegét emeli ki, amely támogatja a technológiai kompetencia definíció átfogó értelmezésének szükségességét.

\section{Az új technológiák kihívásai a technológiai kompetenciák kapcsán}

Miközben napjainkban számos területen igen jelentôs és kiterjedt változások folynak, levezethetôk azok a technológiai trendek, amelyek hatással vannak a különböző ágazatok, szakterületek fejlődésére. E téren nemcsak a tudományos forrásokra, hanem a különböző iparági elemzők kutatásaira is lehet támaszkodni. A kutatások egyik célja annak megértése, hogy a technológiai hatások hogyan értelmezhetők az értékteremtési folyamatok szintjén. Ennek kettős megközelitése a humán oldali és a technikai technológiai képességek, kompetenciák vizsgálata. 
A két nézőpont fontosságára több kutató is rámutatott, itt hivatkozzuk Radu (2020) elemzését.

A jelentős technológiai átalakulások közül az egyik leginkább meghatározó az Ipar 4.0, amely számos szálon kötődik a tudásmenedzsment különböző területeihez. Az Ipar 4.0 kihívásaira reflektáló tudásmenedzsment, illetve döntéshozatali stratégiák témakörét elemezte Abubakara et.al. (2017) publikációja. A szerzők rámutattak, hogy a vállalatok számára komoly kihívást jelent keretrendszerbe foglalni ezen technológiai kompetencia tényezőket. Nagyban meghatározza a vállalat jövőjét a menedzsment, azaz a vezetôk szerepe, hiszen általuk dől el, hogy a technológiai változásokra való reagálás, döntéshozatal és menedzselés, milyen mértékben képes sikerre vinni a vállalatot. A sikertényezők egyértelmủen a kompetenciákhoz kapcsolódóan keresendők, hiszen kulcskérdés, hogy a munkatársak rendelkeznek-e az új technológiákhoz szükséges, megfeleló képességekkel és tudással, amellyel elősegithető a sikeres technológiaváltás. Abubakar és kutatótársai a hagyományos tudásmenedzsment és az ipari fejlődés kapcsolatát vizsgálták, és kiemelték, hogy a döntéshozatal (racionális vagy intuitív) nagy szerepet játszik a tudásmenedzsment és szervezeti teljesítmény között. Ennek oka lehet, hogy az új technológiai kihívások új tudásokat teremthetnek, amelyek még rendezetlennek tűnhetnek. A döntéshozatali stílus is releváns aspektusa az új technológiák és a menedzsment eszközök, módszerek alkalmazásának. Az intuitív szemléttel ellentétben a racionális döntéshozatal elutasithat olyan megoldásokat, amelyekben nem lát logikát, ez pedig egy megjelent új technológia esetében „veszélyes” lehet, hiszen nem feltétlen láthatóak az ismeretlennel szemben a kiszámítható lépések.

Természetesen az Ipar 4.0-tól eltérő technológiai átalakulást is lehetne példaként hozni, ám ez egy viszonylag kutatott és jól értelmezhető irányzat. Érdemes e témakörben megemlíteni Grzybowska és Lupicka (2017) írását is. Az Ipari 4.0 dinamikus fejlődést képes produkálni, amelyhez képzettebb menedzsereket igényel. Ugyanakkor szakképzett vezetői munkaerőre és termelési munkaerőre is szükség van, akik kellő szakértelemmel rendelkeznek az új anyagokkal, gépekkel és információkkal szemben. A szerzők kutatásaik alapján meghatározták azokat a fő kompetenciákat, amelyekre szükség lehet az Ipar 4.0 kihívásai nyomán: kreativitás, vállalkozói gondolkodás, problémamegoldás, konfliktusmegoldás, döntéshozatal, elemzési készségek, kutatási készségek, hatékonyság-orientáció. Ezek mindegyike jelentőséggel bír a vállalatok sikeres technológiai átalakulása során, de kiemelkedően fontos a kutatási készségek és kompetenciák köre, hiszen 
ez alapvető az új technológiák elsajátításához, bevezetéséhez és továbbfejlesztéséhez.

A sort hosszasan lehetne folytatni, hiszen például a digitalizáció szintén kihívásokat okozhat a kompetenciák oldaláról, miközben a vállalatoknak meg kell találniuk az egyensúlyt a technológiai és az emberi tényező között. Ezt a területet vizsgálta Letmathe és Schinner (2017), és kiemelték, hogy minden bizonnyal nagyobb befektetésre lesz szükségük a munkaerő képesítéséhez és összeállításához. Megkérdőjelezhető, hogy a hagyományos tudás- vagy képességtesztek ki tudják mutatni azt, hogy emberek képesek lesznek megbirkózni az új technológiák kapcsán a munkájukkal járó feladatokkal. Különösen az új technológiákkal járó problémákkal és feladatokkal. Ennek okán javasolt a kompetenciák olyan irányú vizsgálata, amely a tudás alkalmazásának pillanatában méri, így válnak mérhetővé a cselekvések által elért eredmények. Továbbra is fontos ugyanakkor éles különbséget kell tenni a szervezeti és az egyéni szintű kompetenciák között. A szervezeti kompetenciamenedzsmentet fontos összehangolni a technológiával és folyamatokkal, majd ezt követően lehet megállapítani az egyének számára releváns kompetenciákat az új technológiák kapcsán.

\section{KÖVETKEZTETÉSEK}

A tudásmenedzsment fogalmi meghatározására és modell szintű ábrázolására rendelkezésre áll megfelelő mennyiségű és minőségű tudományos cikk. Ellenben, kevés az olyan esettanulmány irányultságú, amely segítene a tudásmenedzsment módszertani használatát közelebb hozni, hiszen a tudásmenedzsment alkalmazása szinte minden esetben egyedi lehet. Gyakorlati jelenség az is, hogy a vállalatok vezetése hiába van tisztában a tudásforrásokból származó lehetőségekkel, még sincs konszenzus a tudás a jellemzőivel és a tudásforrások felhasználási módjával kapcsolatban. Ennek kapcsán a tanulmány egyik legfontosabb megállapítása, hogy egy szervezet alapvetöen a tagjainak tudásával rendelkeqik (i), és az egyéneken keresztül értelmezhetô" a szervezeti tudás (ii). A K+F szervezeti tevékenységek során ugyanúgy központi kérdés ezért, hogy milyen egyénekből alakítható ki optimálisan a $\mathrm{K}+\mathrm{F}$ csoport. Kulcskérdés továbbá, hogy miként kell menedzselni a szervezet számára szükséges tudást, ennek alapkérdése, hogy melyek a szükséges tudáselemek. A cikek logikai okfejtése nyomán összefüggések állapíthatók meg a tudásmenedzsment és a technológia, illetve technológiai menedzsment (iii) között. Bár koncepcionális szinten látszik a kutatók összhangja, ugyanakkor a tudományos források teljes 
komplexitásában kevésbé foglalkoznak a témával mélyebb vizsgálatokon keresztül. Az egyes kutatások ezeket külön-külön megemlítik, de a kulcskapcsolatokra és azok egymásra hatására nem térnek ki részletesen. Az elmúlt évtizedben az új technológiák (pl. 5G, 3D nyomtatás, autonóm jármúvek stb.) kiemelkedő fontosságra tettek szert, mivel számos ipari területen igen jelentôs átalakulások folynak. Ennek kapcsán jól látszik, hogy a gyors és elérhető információáramlás, a koncepcionális kutatások és a fejlesztési fázisok párhuzamosítása, a korábbi merev kutatási szakasz határok elmosódása katalizáló hatást gyakorol a kutatások intenzitására, illetve a fejlesztési tevékenységek stratégiai jellegére. A piaci szereplők számára létfontosságú kérdés, hogy ezen vezető technologiákat idôben lekövessék és elsajátitsák, ennek lényeges eszoöze lehet a tudásmenedzsment (iv). A technológiai területtel szinte minden szervezet foglalkozik, de valódi $\mathrm{K}+\mathrm{F}$ tevékenységekkel leginkább a tudásalapú szervezetek foglalkoznak.

A tudásalapú szervezetek számára még inkább fontos a technológiai trendek figyelése, illetve a $\mathrm{K}+\mathrm{F}$ tevékenységek módszeres menedzselése, amelyen belül a tudásmenedzsment kiemelkedő szerepet kell, hogy betöltsön. Lényeges megemlíteni továbbá, hogy a vezetô technológiákkal foglalkozó szervezeteknek ügyelniük kell a technológiai hatásokra, illetve az innovációk okozta tovagyűrűző következményeire is. Általában ezek olyan szerteágazó hatások, amelyek kilépnek a szervezetek saját hatóköréből. Egy-egy új technológia vagy innováció megjelenése már más tudást kívánhat, a $\mathrm{K}+\mathrm{F}$ tevékenységben résztvevő csoportokban más szakemberekre lesz szükség, az új tudás megszerzése más módszereket igényelhet stb., tehát a tudásmenedżsment és a $K+F$ erös kapcsolatban állnak. (v). Emellett fontos a $\mathrm{K}+\mathrm{F}$ tevékenységre létrehozott csoport összetétele, amely szintén a tudásmenedzsment oldaláról építhető fel optimálisan. Az ilyen jellegú feladatok, projektek mindig egyediek, hiszen különböző menedzsment módszereket kell alkalmazni. Így a projekt során szükséges tudás elsajátitására és létrehozására megfelelő egyénekből csoport felállítása indokolt, illetve a megfelelő módszerek megválasztása is fontos.

A tudásmenedzsment technológiai irányú kivetítése a technológiai kompetencia fogalmának mélyebb értelmezésével világítható meg. A technológiai kompetencia ipari megközelítése kapcsán a kutatók szinte egységes definíció-üzenete az, hogy a technologiai kompetencia a bumán jellegü képességek és a technikai képességek egyvelege (vi). Végül, de nem utolsósorban a tudásmenedzsment és a $\mathrm{K}+\mathrm{F}$ számára nem csak a belső környezet fontos, hanem a külső környezet is. Meghatározó az oda-vissza múködő kapcsolat más szervezetekkel (pl.: triple helix modell). Így a 
tudásmenedzsment folyamat során meghatározható egy input (valamilyen forrásból származó bemenet) és egy output (termék vagy szolgáltatásként) oldal. Ennek a megközelítésnek az értelmezéséhez az 5. ábrán látható modell használható, amely lényegében a technológiai kompetencia gyakorlati értelmezésének egy lehetséges formája; nem egyéni szinten, hanem tevékenységi szinten ábrázolja a $\mathrm{K}+\mathrm{F}$ tevékenység kapcsolódásait, visszacsatolásait a tudásmenedzsment szemszögéből, felhasználva a jelen tanulmány következtetéseit.

- Összegezve, a tudás fogalmától a technológiai kompetenciáig terjedô tartalmi íven végig vitt szakirodalmi összefoglalók, az azokat összekapcsoló értelmező kiegészítések, valamint a levezetés egyes pontjain megfogalmazott megállapítások egészéből a következő, a technológiai környezetben releváns tudásmenedzsmenttel kapcsolatos megfogalmazások tehetők:

- egy szervezet alapvetóen a tagjainak tudásával rendelkezilk (i),

- az egyéneken keresżtïl értelmez̧hetó a szervezeti tudás (ii),

- összefüggések állapíthatók meg a tudásmenedzsment és a technológia, illetve technológiai menedzsment kö̈zött (iii),

- ahhoz, hogy a technológiákat idôben lekövessék és elsajátitsák, ennek lényeges eszköze lehet a tudásmenedzsment (iv),

- a tudásmenedzsment és a kutatás-fejlesztés erös kapcsolatban állnak. (v),

- a technológiai kompetencia a humán jellegü képességek és a technikai képességeek egyvelege (vi).

Az itt felvetett 6 következtetés mindegyike további kutatások tárgya lehet, de éppen ez volt a tanulmány egyik célja, nevezetesen számba venni a fó elméleti forrásokat, majd javaslatokat megfogalmazni további kutatások lehetőségével kapcsolatban. 


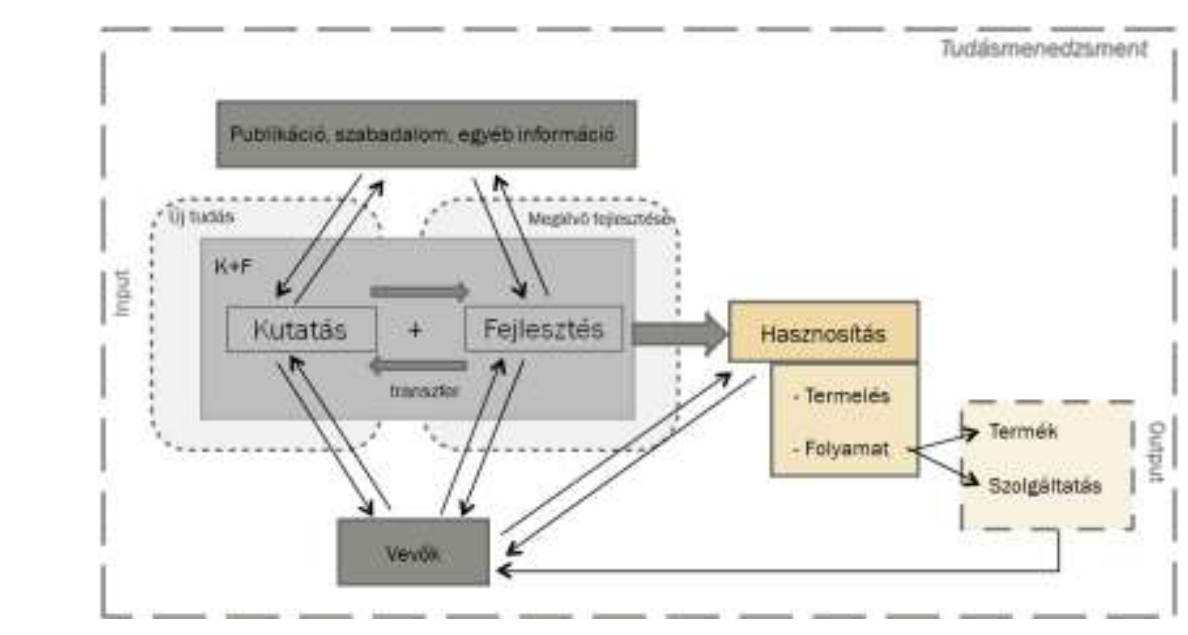

6. ábra. $\mathrm{K}+\mathrm{F}$ tevékenységek kapcsolati hálói a tudásmenedzsment keretében, mint a technológiai kompetencia gyakorlati értelmezése Forrás: Saját szerkesztés

„AZ INNOVÁCIÓS ÉS TECHNOLÓGIAI MINISZTÉRIUM KOOPERATÍV DOKTORI Program DokTori Hallgatói Ösztöndíj ProgramjánaK a NemZeti KUTATÁSI, FEJLESZTÉSI ÉS INNOVÁCIÓS ALAPBÓL FINANSZÍROZOTT SZAKMAI TÁMOGATÁSÁVAL KÉSZÜLT.” "y

\section{FELHASZNÁLT IRODALOM}

1. Abubakar, M. A., Elrehail, H., Alatailat, M. A., Elci, A. (2017): Knowledge management, decision-making style and organizational performance, Journal of Innovation \& Knowledge

2. Aleksandr I. Kashirin (2018): Method of managing unique technological competencies. International Journal of Mechanical Engineering and Technology (IJMET) Volume 9, Issue 12, December 2018, pp. 1256-1266

3. Anagnostopoulos, C. N. (1998). Few gold stars for precollege education. IEEE Spectrum, 18-26. https://doi.org/10.1109/6.666954

4. Arballo N. C., Nunez M. E. C., Tapia B. R. (2019): Technological Competences: A Systematic Review of the Literature in 22 Years of Study, International Journal of Emerging Technologies in Learning, Vol 14, No 04 (2019)

5. Armand Hatchuel; Pascal Le Masson; Benoiit Weil (2002): From knowledge management to design-oriented organisations, International Social Science Journal 
6. Bell, M., \& Pavitt, K. (1993). Technological accumulation and industrial growth: contrasts between developed and developing countries. Industrial and corporate change, 2 (2), 157-211. https://doi.org/10.1093/icc/2.2.157

7. Bencsik, Andrea; Für, Klaudia (2015): Olcsó és okos - A frugal innovációs és a tudásmenedzsment szimbiózisa, XLVI. ÉVF. 2015. 12. szám/ ISSN 0133-0179

8. Bencsik, Andrea (2015): A tudásmenedzsment elméletben és gyakorlatban, Budapest ISBN: 9789630597845

9. Berényi, László (2012): Kompetenciamenedzsment és irányításirendszerszabványok, Debreceni Egyetem

10. Castro, G. M. (2015): Knowledge management and innovation in knowledgebased and high-tech industrial markets: The role of openness and absorptive capacity, Industrial Marketing Management

11. Demeter, Krisztina; Losonci, Dávid; Kovács, Zoltán (2017): A lean tudás megosztása, Budapesti Corvinus Egyetem, ISBN 978-963-503-666-0

12. Fehér, Péter (2005): A technológiák szerepe a tudásmenedzsment folyamatok támogatásában, Vezetéstudomány, Budapest

13. Fernández, M. R. (2003). Competencias profesionales del docente en la sociedad del siglo XXI. Revista Fórum Europeo de Administradores de la Educación, 11 (1).

14. Ganesh D. Bhatt (2001): Knowledge management in organizations: examining the interaction between technologies, techniques, and people, Journal of Knowledge Management Volume 5 Number 12001 pp. 68-75

15. Giget, M. (1997). Technology, innovation and strategy: recent developments. Internacional Journal of Technology Management, 14, 613-634. https://doi.org/10.1504/IJTM.1997.

16. Giget, M. (1984). The Bonsai tree of Japanese industry. FUTURES.

17. Grzybowska, K., Lupicka, A (2017): Key competencies for Industry 4.0, Economics \& Management Innovations(ICEMI)

18. Hlupic, V. (2002). Knowledge and Business Process Management. (I. G. (IGI), Ed.) ilustrada.

19. Jia-Sheng Lee, Wan-Fai Chou (2009): The effect of knoledge management strategy of an enterprise ont he knowledge creation capability of R\&D team members and their R\&D performance, Taiwan

20. Kajati, György (2013). K+F, innováció és projektmenedzsment. Eger: Eszterházy Károly Főiskola

21. Kashif Akram; Suleman Hafeez Siddiqui; Muhammad Atif Nawaz (2011): Role of Knowledge Management to Bring Innovation: An Integrated Approach, International Bulletin of Business Administration ISSN: 1451-243X Issue 11 (2011)

22. Keczer, Gabriella (2016): A tudásmenedzsment és az emberi erőforrás menedzsment kapcsolata - A tudásmegosztás elősegítése a szervezetben, Szeged

23. Letmathe, P., Schinner, M. (2017): Competence Management in the Age of Cyber Physical Systems, Industrial Internet of Things (pp.595-614)

24. Mariano Nieto (2002): From R\&D management to knowledge management An overview of studies of innovation management, Technological Forecasting and Social Change 
25. Mihir, Parikh (2015): Knowledge Management Framework for High-Tech Research and Development, Engineering Management Jorunal

26. Morcillo, P. (1997). Dirección estratégica de la tecnología e innovación. Madrid.

27. Nieto, M. (2004). Basic propositions for the study of the technological innovation process in the firm (Vol. 7). European Journal of Innovation Management. https://doi.org/10. 1108/14601060410565065

28. Nonaka, I. and Takeuchi, H. (1995). The Knowledge-Creating Company: How Japanese Companies Create the Dynamics of Innovation. Oxford University Press, New York.

29. Pataki, Béla (2005): A technológia menedzselése, Budapest ISBN 9639548707

30. Prahalad, C., \& Hamel, G. (1990). The core competences of the corporation (Vol. 68). Harvard Business Review.

31. Prahalad, C., \& Hamel, G. (1994). Competing for the future. Harvard Business School.

32. Radu, L. D. (2020): Disruptive Technologies in Smart Cities: A Survey on Current Trends and Challenges, Smart Cities 2020, 3, 1022-1038, pp.3; doi:10.3390/smartcities3030051

33. Sh. U. Kosimov, M. R. Rafiqova, M. I. Murodova (2021): Implementation of the Technological Competence of Future Specialists. Scientific Research Publishing Inc. Creative Education, 2021, 12, 666-677; ISSN Online: 2151-4771

34. Stephen J. Kline, Nathan Rosenberg (1986): An Overview of Innovation. In Landau, R.-Rosenberg N. (1986): The Positive Sum. National Academy Press. Washington.

35. Tyler, B. B. (2001). The complementarity of cooperative and technological competencies: a resource-based perspective. Journal Engineering and Technology Manegement Jet-M, 18, 1-27. https://doi.org/10.1016/S09234748(00)00031-X

36. Vallejo, B. M., Gallo, J. J., \& Plazas, C. E. (2016). Propuesta de una metodología para el estudio de competencia tecnológica en empresas fabricantes de medicamentos. Universidad \& Empresa, 18 (31), 11-27. https://doi.org/10.12804/rev.univ.empresa.31.2016.01

37. Wu Yang; ZhongJing-jun; Sun Chang-xiong (2007): The Fusion Model of Knowledge Management and Communication Management in Research Organization, China 
ISSN 2630-886X

18 国 57
BGE 